УдК 327 : 341.1

\title{
УКРАЇНО-БОЛГАРСЬКІ ВІДНОСИНИ В КОНТЕКСТІ ЄВРОПЕЙСЬКОЇ ІНТЕГРАЦІЇ
}

\section{Братко Ірина Василівна}

Надіслано:

13.03.2019

кандидат юридичних наук, доцент, Київський університет імені Бориса Грінченка, Рецензовано: 24.03.2019 м. Київ, Україна ORCID: 0000-0002-8979-3232 10.04.2019

i.bratko@kubg.edu.ua

У статті розглядаються питання формування та розвитку добросусідських відносин між Україною та Болгарією 3 огляду на євроінтеграційні устремління нашої держави. Метою статті було висвітлення перспектив розвитку двосторонніх відносин на основі існуючих міжнародних договорів та дипломатичних контактів. Застосування історикопрогностичного методу для дослідження відносин між країнами та контентаналізу міжнародно-правових документів дозволило дослідити позитивний вплив Договору про асоціацію між Україною та ЄС на розвиток двосторонніх міжнародних відносин. Визначено можливості розширення двосторонніх відносин на основі чинних двосторонніх договорів між країнами та Договору про асоціацію.

Ключові слова: Україна; Болгарія; міжнародні відносини; економічна співпраця;міжнародні договори.

Bratko Iryna, Ph.D. (law), Associate Professor, Borys Grinchenko Kyiv University, Kyiv, Ukraine

Ukraine-Bulgarian relations in the context of European integration

The article deals with the formation and development of good-neighbouring relations between Ukraine and Bulgaria due to the Euro-integration aspirations of our state. The main object of the study is to highlight the prospects for the development of bilateral relations on the basis of existing international treaties and diplomatic contacts. The use of the historical and prognostic method in the study of relations between countries and the content analysis of international legal documents made it possible to investigate the positive impact of the Association Agreement between Ukraine and the EU on bilateral relations between countries and determine the possibilities of expanding these relations on the basis of existing international agreements.

Key words: Ukraine; Bulgaria; international relations; economic cooperation; 


\section{Братко Ірина Василівна \\ Україно-болгарські відносини \\ в контексті європейської інтеграції}

international treaties.

Братко Ирина Николаевна, кандидат юридических наук, Киевский университет имени Бориса Гринченко, г. Киев, Украина

\section{Украино-болгарские отношения в контексте европейской интеграции}

В статье рассматриваются вопросы формирования и развития добрососедских отношений между Украиной и Болгарией, учитывая евроинтеграционные устремления нашего государства. Целью статьи является освещение перспектив развития двусторонних отношений на основе существующих международных договоров и дипломатических контактов. Применение историко-прогностического метода при исследовании отношений между странами и контент-анализа международно-правовых документов позволило исследовать положительное влияние Соглашения об ассоциации между Украиной и ЕC на двусторонне отношения между странами и определить возможности расширения этих отношений на основе действующих международных договоров.

Ключевые слова: Украина; Болгария; международные отношения; экономическое сотрудничество; международные соглашения.

\section{Вступ}

Добросусідські та взаємовигідні відносини між країнами, що базуються на взаємній повазі та дотримання міжнародного права, $є$ основою сучасного сталого розвитку та забезпечують процвітання країн. Україна, внаслідок свого унікального геополітичного положення, має широкі можливості для розвитку багатогранних міжнародних відносин 3 державами-сусідами. Серед таких держав особливе місце займає Республіка Болгарія.

Між Україною і Болгарією існує тісний історичний і культурний зв'язок, що вибудовувався протягом багатьох століть. Сучасне співробітництво двох країн націлене на забезпечення миру, активізацію зовнішньоекономічних зв'язків і, в цілому, на створення безпечної зони стабільного економічного та політичного співробітництва між державами-сусідами.

\section{Аналіз останніх досліджень та публікацій}

Питання двосторонніх відносин між Болгарією та Україною привертають увагу вчених та розглядаються як плодотворні та перспективні відносини між двома незалежними державами, що мають спільні національні інтереси та культурну спадщину. Міжнародному співробітництву між Болгарією та Україною приділяли увагу такі вчені як Г. Мінгазутдінова, Л. Ченик, П. Лозинський, Г. Семеніхин. Особливий інтерес для дослідників представляє питання співробітництва між Україною та Болгарією 
у Чорноморському регіоні, що розглядається у роботах В.Кравченко, А. Гудакова та ін.

\section{Виділення невирішених раніше частин загальної проблеми}

Після укладання Договору про асоціацію між Україною та ЄС питання ефективного міжнародного співробітництва між країнами-членами Європейського Союзу отримали нові перспективи. Сучасне співробітництво між Україною і Болгарією стосуються багатьох сфер суспільного життя та підкріплені міжнародними угодами різного рівня, і які вимагають детального аналізу та виявлення перспектив подальшого співробітництва між країнами.

\section{Формулювання цілей статті}

Метою статті є аналіз міжнародних відносин між Україною та Болгарією, що мають спільні кордони на суші та на морі, а також визначення перспектив подальшого розвитку цих відносин з врахуванням зацікавленість України упідтримці країн-членів ЄС на шляху до членства України в цьому регіональному об'єднанні; виявлення тенденцій та пошук перспективних напрямів двостороннього та регіонального співробітництва.

\section{Виклад основного матеріалу дослідження}

Співробітництво між незалежними Україною та Болгарією інтеграції розпочиналось на фоні інтеграції Болгарії до Європейського Союзу.

У 90-ті pp. ХХ ст. Болгарія заклала основи для здійснення європейської інтеграції. У червні 1990 р. країна отримала статус спеціально запрошеного учасника Парламентської Асамблеї Ради Європи (ПАРЄ), у травні 1992 р. була прийнята до Ради Європи; у лютому 1994 р. у Болгарія приєдналась до програми НАТО «Партнерство ради миру»; 1 лютого 1995 р. отримала статус асоційованого члена ЄС; 16 грудня 1995 р. країна подала заявку до вступу у ЄС, а в грудні 1999 р. отримала запрошення до початку переговорів до приєднання до ЄC (Dosvid yevrointehratsii Bolharii. Analitychna zapyska, 2019).

У результаті активного співробітництва в рамках європейської інтеграції та взаємодії 3 країнами трансатлантичного альянсу Болгарія в листопаді 2002 р. отримала членство в НАТО, а у квітні 2005 р. Європейський парламент проголосував за вступ Болгарії до ЄС у січні 2007 р., не зважаючи на скептичне ставлення до цього деяких європарламентарів на підставі наявних проблем реформування системи судочинства і низької ефективності боротьби з корупцією (Dosvid yevrointehratsii Bolharii. Analitychna zapyska, 2019).

Саме у цій складний період відбувався розвиток взаємовигідних зовнішньополітичних та економічних зв'язків між незалежними Україною та Республікою Болгарія. Після проголошення незалежності нашої держави, Болгарія однією 3 перших країн визнала незалежність України 


\section{Братко Ірина Василівна \\ Україно-болгарські відносини \\ в контексті європейської інтеграції}

(5 грудня 1991 р.) і вже 13 грудня цього ж року встановила дипломатичні відносини. Сьогодні між Болгарією та Україною підписано більш ніж 80 міжнародних угод, які стосуються врегулюванні питань економічного співробітництва, зовнішньої торгівлі, надання правової допомоги, енергетики, захисту навколишнього середовища тощо (Mizhrehionalne spivrobitnytstvo mizh Ukrainoiu ta Bolhariieiu, 2018).

Украина розглядає Болгарію як надійного економічного та політичного партнера в Південно-Східній Європі. За результатами 2018 р. зустрічна торгівля між країнами склала 650 млн дол. (Ukraina rozghliadaie Bolhariiu yak druzhniu krainu i nadiinoho partnera..., 2019).

Сучасний політичний діалог між дружними країнами стосується питань державної безпеки та обороноздатності. Уряд України зауважує про необхідність мати політичну підтримку у протидії агресії Росії, в координації з української зовнішньополітичної позицією щодо припинення агресії Росії, для чинення тиску на Уряд Російської Федерації для негайно звільнення українських політичних в'язнів і заручників (Ukraina rozghliadaie Bolhariiu yak druzhniu krainu i nadiinoho partnera ..., 2019).

Співпраця між Україною та Болгарією в рамках роботи міжнародних організацій, що забезпечує інтеграцію України в європейський політичний, економічний і правовий простір перебуває під контролем урядів України і Болгарії, і спрямоване на досягнення критеріїв, необхідних для членства України в ЄС (Mizhnarodne spivrobitnytstvo, 2018).

У цьому контексті багатопланове співробітництво України з НАТО підкріплюється двосторонніми міжнародними угодами, серед яких особливе місце займає Договір між Міністерством соціальної політики України та Міністерством оборони Республіки Болгарія в рамках Трастового фонду НАТО в сфері медичної реабілітації в Україні від 3 жовтня 2017 р. Болгарії відведено провідну роль у реалізації програми Трастового фонду НАТО медичної реабілітації та протезування поранених (Угода між МСПУ та МОБ, 2018). За інформацією Міноборони України за цією програмою медичні установи Болгарії планують протягом двох років, починаючи з 2017 р., прийняти близько 300 травмованих учасників бойових дій на сході України для реабілітації (U ramkakh Trastovoho Fondu NATO v Bolhariiu..., 2018).

Найбільш успішні напрямки двостороннього співробітництва спостерігаються в сфері найбільших спільних інтересів двох країн і дозволу спільних проблемних питань. Йдеться про організацію прямого авіаційного та залізничного сполучення, реалізацію високотехнічного проекту АЕС «Козлодуй», створення сприятливих умов у торгово-економічній галузі (Ukraina rozghliadaie Bolhariiu yak druzhniu krainu i nadiinoho partner..., 2019). Зокрема, виключення Республіки Болгарія 3 переліку країн, до яких 
застосовується законодавство про трансферне ціноутворення, що дозволить врегулювати митні питання і зняти адміністративні бар'єри в торговельних відносинах між країнами.

Підписання Договору про асоціацію між Україною, з одного боку, та Європейським Союзом, Європейським співтовариством з атомної енергії та їх державами-членами, 3 іншого боку від 27.06.2014 p. в редакції від 30.11.2015 р. (далі - Договір про асоціацію) (Uhoda pro asotsiatsiiu mizh Ukrainoiu..., 2014) відкрило нову сторінку для відносин між Україною, ЄC та державами-членами Європейського союзу. Положення ст. 479 Договору про асоціацію складають основу для розвитку двостороннього співробітництва з державами-членами ЄС.

Значимість ст. 479 Договору про асоціацію важко переоцінити. Насамперед, ця стаття розв'язує «колізію» двох угод між Україною з ЄС: Угоди про партнерство та співробітництво між Україною, з одного боку, і Європейськими Співтовариствами та їх державами-членами, з іншого боку від 14 червня 1994 р. (Uhoda pro asotsiatsiiu mizh Ukrainoiu..., 2014) і Договору про асоціацію. Пунк 1 ст. 479 Договору про асоціацію вказує на втрату дієвості Договору про партнерство і співробітництво. При цьому, пунктом 2 ст. 479 визначається, що Договір про асоціацію замінює Договір про партнерство та співробітництво і всі попередні відсилання в угодах наразі відносяться до Договору про асоціацію. Одночасно ст. 479 Договору про асоціацію враховує особливості перехідного періоду імплементації цієї угоди, зокрема, вирішує питання про забезпечення прав фізичних осіб в рамках виконання попередніх договірних зобов'язань сторін угоди (п. 3 ст.479). Ця стаття Договору про асоціацію стосується також питання двостороннього співробітництва держав-членів, що є, на думку автора, дуже важливим для врегулювання відносин між Україною і Болгарією. Пункт 6 ст. 479 містить положення, відповідно до якого реалізація Договору про асоціацію не впливає на розвиток двосторонніх відносин між Україною та державами-членами і на підписання нових угод між ними. Таке право обмежується тільки положеннями Договору про Європейський Союз та Договору про функціонування Європейського Союзу, які стосуються спільних інтересів ЄС.

у контексті Договору про асоціацію вбачається, що попередні та наступні угоди між Україною, Європейським Союзом і державами-членами, мають складати єдину правову базу. Це $\epsilon$ правовою основою побудови інституційних механізмів реалізації Договору про асоціацію (п. 4 і 5 ст. 479). Інституційна складова Договору про асоціацію - своєрідний «двигун» виконання договірних зобов'язань. Європейським Союзом розроблені і застосовуються дуже багато різноманітних i дієвих правових та комунікативних механізмів і платформ для активізації співпраці між країнами. 


\section{Братко Ірина Василівна \\ Україно-болгарські відносини \\ в контексті європейської інтеграції}

Важливим $\epsilon$ також те, що застосування цих механізмів ефективно не тільки в рамках відносин Україна-ЄС, а також при регулюванні регіональних і двосторонніх відносин за участю держав-членів ЄС.

3 огляду на підписання Договору про асоціацію і політичний курс України на європейську інтеграцію, для України представляє цінність досвід Болгарії у реформування економіки відповідно до вимог ЄС та адаптації національного законодавства до права ЄС. Завдяки правовій основі для плідної передачі досвіду сторони мають можливість задіяти Меморандум про партнерство i поглиблення співробітництва в сфері європейської та євроатлантичної інтеграції між Кабінетом Міністрів України та Урядом Республіки Болгарія від 29 листопада 2005 p. (Memorandum pro partnerstvo i pohlyblennia spivrobitnytstva..., 2005), підписаний в рамках двостороннього співробітництва ще до підписання Договору про асоціацію.

Розвиток взаємовигідного співробітництва на рівні міст в останні роки набирає обертів і створює умови для активізації бізнес-партнерства і соціальних контактів між країнами. Сьогодні між областями України підписано десять угод, що визначають міжрегіональне співробітництво Україна-Болгарія між містами-побратимами. Побратимські відносини встановлені між містами Київ і Софія, Харків і Варна, Глухів та Свиштов, Бердянськ і Ямбол, Житомир та Монтана, Запоріжжя та Бургас, Луцьк і Пазаржик і багатьма іншими містами двох країн (Posolstvo Ukrainy v Respublitsi Bolharii).

Муніципальна дипломатія на основі взаємодії адміністрацій містпобратимів і розвиток міжмуніципальних зв'язків $є$ характерною особливістю міжнародних відносин між Україною i Республікою Болгарія. Саме встановлення прямих контактів між областями, муніципалітетами, діловими колами сприяє інтенсифікації торговельно-економічних відносин, розвитку партнерських відносин у сфері освіти, науки, культури, туризму і міського самоврядування. Цей рівень україно-болгарського співробітництва поступово стає основою ефективних міждержавних контактів в економічній, туристичній, освітній та культурній сфері суспільних відносин. Країни мають широкі можливості використовувати вже наявні двосторонні механізми співробітництва та умови обміну позитивним досвідом самоврядування i децентралізації, а також впроваджувати нові механізми взаємовигідного співробітництва.

Вагомою складовою двосторонніх відносин між Україною-Болгарією є співробітництво в гуманітарній сфері. На основі Угоди між Урядом України та Урядом Республіки Болгарія про співробітництво в галузях освіти, науки і культури від 5 жовтня 1992 р. (Угода з освітніх питань, 1992) та міжвідомча Угода між Міністерством України у справах науки і технологій та Міністерством 
освіти і науки Республіки Болгарія в сфері науково-технічного співробітництва від 24 березня 1998 р. (Uhoda mizh Ministerstvom Ukrainy u spravakh nauky i tekhnolohii..., 1998), а також ряду предметних протоколів до цих угод, сторони мають можливість проводити щорічний обмін студентами, аспірантами і стажистами науково-дослідної роботи та навчання в Україні і Болгарії.

Підписання рамкового Договору між Болгарською академією наук і Державним космічним агентством України про співпрацю в рамках космічного експерименту «Іоносат-Мікро» на космічному апараті «Мікросат-M» (Uhoda mizh Bolharskoiu akademiieiu nauk ta Derzhavnym kosmichnym ahentstvom Ukrainy..., 2016) можна розглядати як позитивний приклад секторальної інтеграції між двома державами.

За цією угодою науковці України, Польщі та Болгарії мають здійснити космічний експеримент, одним 3 компонентів якого $\epsilon$ інструментарний комплекс Іонний дрейфометр IД-2 («Iondriftmeter ID-2»), розроблений Інститутом космічних досліджень і технологій Болгарської академії наук і який має стати частиною бортового обладнання «Іоносат-Мікро» (Ionosat-Micro). Цим документом також передбачено співробітництво в молодіжній сфері. Підписаний між країнами меморандум надасть можливість здійснювати обмін делегаціями та інформацією між молодіжними організаціями, установами, які здійснюють діяльність щодо реалізації державної політики у молодіжній сфері, проводити спільні фестивалі, конференції, тренінги, конкурси, розробляти та реалізовувати спільні проекти у сфері популяризації здорового способу життя молоді, залучення до волонтерської діяльності, розвитку міжкультурного діалогу (Ionosat-Micro).

Загальносвітова тенденція об'єднання ресурсів декількох країн для створення оптимальної моделі спільного вирішення економічних, політичних, соціальних і культурних проблем регіонального значення, які входять в коло національних інтересів, але виходять за рамки їх юрисдикції, досить яскраво проявляється в Чорноморському та Придунайському регіонах. Стратегічне співробітництво з державами цього регіону спрямоване на забезпечення миру, активізацію зовнішньоекономічних зв'язків і, в цілому, на створення безпечної зони стабільного економічного та політичного співробітництва між державами. Дослідники питань регіонального розвитку вбачать у цьому формування «південного вектора» євроінтеграційної стратегії України та вказують на потенціал і важливість конструктивної співпраці в цьому регіоні (Semenikhin, 2013; Chernyk, Lyzynskyi, 2009, p. 245; Minhazutdinova, 2019). Економісти розглядають потенціал розвитку портів Чорноморського регіону і посилення транспортних вантажопотоків і експортно-імпортних операцій в цьому регіоні (Kravchenko, Hudakov, 2013, p. 225). 


\section{Братко Ірина Василівна \\ Україно-болгарські відносини \\ в контексті європейської інтеграції}

\section{Висновки і перспективи подальшого розвитку}

Українсько-болгарське співробітництво розширює межі політичних і економічних можливостей, дозволяє комплексно використовувати правові механізми двостороннього, регіонально співробітництва, а також можливості співпраці в рамках європейської інтеграції України.

Співпраця між Україною та Болгарією закріплена міжнародними угодами різного рівня на умовах рівноправного партнерства і відображають їх національні інтереси. Договір про асоціацію містить універсальні механізми, які сприятимуть розвитку двосторонніх відносин між Україною та Болгарією.

Серед перспективних механізмів співпраці між державами варто виокремити муніципальну дипломатію, що забезпечує можливість створення і реалізації взаємовигідних проектів, співробітництво в освітній та науковій сферах, а також регіональне співробітництво в рамках Чорноморського регіону і Придунайського басейну, які мають значний потенціал.

\section{References:}

1. Chernyk P., Lyzynskyi, P. (2009). 'Osoblyvosti suchasnykh ukrainskobolharskykh dvostoronnikh vidnosyn' [Features of modern Ukrainian-Bulgarian bilateral relations].Naukovyi visnyk Uzhhorodskoho universytetu. Seriia: politolohiia, sotsiolohiia, filosofiia [Scientific Bulletin of Uzhgorod University. Series: political science, sociology, philosophy], no. 13, pp. 244-248.

2. Dosvid yevrointehratsii Bolharii. Analitychna zapyska [Experience of European integration of Bulgaria. Analytical note]. (2019). Natsionalnyi instytut stratehichnykh doslidzhen, [online]. Available at: http://www.niss.gov.ua/articles/1412/ [Accessed 02 February2019].

3. Ionosat-Micro, [online]. Available at: http://ionosat-micro.ikd.kiev.ua/ua . [Accessed 05 March 2019].

4. Kravchenko V. O., Hudakov, O.K. (2013). Problemy ta perspektyvy spivpratsi Ukrainy z krainamy OChES v umovakh hlobalizatsii svitovoi ekonomiky [Problems and prospects of Ukraine's cooperation with the countries of the BSEC in the context of globalization of the world economy]. Problemy i perspektivy razvitiya sotrudnichestva mezhdu stranami Yugo-Vostochnoi Evropy v ramkakh ChES i GUAM [Problems and prospects of cooperation between countries of South-Eastern Europe within context of Black Sea economic cooperation and GUAM], pp. 223-228.

5. Memorandum pro partnerstvo i pohlyblennia spivrobitnytstva $\mathrm{v}$ haluzi yevropeiskoi ta yevroatlantychnoi intehratsii mizh Kabinetom Ministriv Ukrainy ta Uriadom Respubliky Bolhariia vid 29.11.2005 r. [Memorandum on partnership and deepening of cooperation in the field of European and Euro-Atlantic integration between the Cabinet of Ministers of Ukraine and the Government of the Republic of Bulgaria, dated 2005, November 29]. Verkhovna Rada Ukrainy [Verkhovna Rada of 
Ukraine], [online]. Available at: http://zakon3.rada.gov.ua/laws/show/100_063 [Accessed 04 March 2019].

6. Minhazutdinova, H. (2018). 'Osnovni napriamky suchasnykh ukrainobolharskykh vidnosyn (1991-2018 rr.)' [The main directions of modern UkrainianBulgarian relations (1991- 2018)]. Yevropeiski istorychni studii [European Historical Studies], [online], no.10. Available at: http://eustudies.history.knu.ua/galynamingazutdinova-osnovni-napryamky-suchasnyh-ukrayinsko-bolgarskyh-vidnosyn1991-2018-rr/ [Accessed 03 March 2019].

7. Mizhnarodne spivrobitnytstvo [international cooperation]. (2018). Ministerstvo oborony Ukrainy [Ministry of Defence of Ukraine], [online]. Available at: http://www.mil.gov.ua/diyalnist/mizhnarodne-spivrobitnicztvo [Accessed 11 June 2018].

8. Mizhrehionalne spivrobitnytstvo mizh Ukrainoiu ta Bolhariieiu [Interregional cooperation between Ukraine and Bulgaria]. (2018). Posolstvo Ukrainy $v$ Respublitsi Bolhariia [Embassy of Ukraine in the Republic of Bulgaria], [online]. Available at: https://bulgaria.mfa.gov.ua/ua/ukraine-bg/regions [Accessed 04 March 2019].

9. Posolstvo Ukrainy v Respublitsi Bolharii [Embassy of Ukraine in the Republic of Bulgaria], [online]. Available at: https://bulgaria.mfa.gov.ua/ua/legal-acts/ [Accessed 05 June 2018].

10. Semenikhin, H. V. (2013). 'Intehratsiini protsesy v Orhanizatsii Chornomorskoho ekonomichnoho spivrobitnytstva. Tendentsii ta perspektyvy' [Integration processes in the Black Sea Economic Cooperation Organization. Trends and Prospects]. Problemy i perspektivy razvitiya sotrudnichestva mezhdu stranami Yugo-Vostochnoi Evropy v ramkakh ChES i GUAM [Problems and prospects of cooperation between countries of South-Eastern Europe within context of Black Sea economic cooperation and GUAM], pp. 338-342.

11. U ramkakh Trastovoho Fondu NATO $\mathrm{v}$ Bolhariiu na reabilitatsiiu vidpravliaietsia hrupa z 10 travmovanykh uchasnykiv boiovykh dii na skhodi Ukrainy [Within the framework of the NATO Trust Fund a group of 10 traumatized combatants is sent to rehab in eastern Ukraine to Bulgaria]. (2018). Ministerstvo oborony Ukrainy [Ministry of Defence of Ukraine], [online]. Available at: http://www.mil.gov.ua/news/2018/06/09/u-ramkah-trastovogo-fondu-nato-vbolgariyu-na-reabilitacziyu-vidpravlyaetsya-grupa-z-10-travmovanih-uchasnikivbojovih-dij-na-shodi-ukraini [Accessed 04 March 2019].

12. Uhoda mizh Bolharskoiu akademiieiu nauk ta Derzhavnym kosmichnym ahentstvom Ukrainy pro spivrobitnytstvo $\mathrm{v}$ ramkakh kosmichnoho eksperymentu «Ionosat-Mikro» na kosmichnomu aparati «Mikrosat-M» vid 30.06.2016 [Agreement between the Bulgarian Academy of Sciences and the State Space Agency of Ukraine on cooperation within the framework of the space experiment "Ionosat-Micro" on the spacecraft "Microsat-M", dated 1026, June 30]. Verkhovna Rada Ukrainy [Verkhovna 


\section{Братко Ірина Василівна \\ Україно-болгарські відносини \\ в контексті європейської інтеграції}

Rada of Ukraine], [online]. Available at: http://zakon3.rada.gov.ua/laws/show/100_100 [Accessed 04 March 2019].

13. Uhoda mizh Ministerstvom sotsialnoi polityky Ukrainy ta Ministerstvom oborony Respubliky Bolhariia v mezhakh proektu Trastovoho fondu NATO u sferi medychnoi reabilitatsii v Ukraini [Agreement between the Ministry of Social Policy of Ukraine and the Ministry of Defense of the Republic of Bulgaria within the framework of the project of the NATO Trust Fund for Medical Rehabilitation in Ukraine]. (2017). Verkhovna Rada Ukrainy [Verkhovna Rada of Ukraine], [online]. Available at: https://zakon2.rada.gov.ua/laws/show/100_002-17 [Accessed 04 March2019].

14. Uhoda mizh Ministerstvom Ukrainy u spravakh nauky i tekhnolohii ta Ministerstvom osvity i nauky Respubliky Bolhariia v haluzi naukovo-tekhnichnoho spivrobitnytstva vid 24.03.1998 r. [Agreement between the Ministry of Science and Technology of Ukraine and the Ministry of Education and Science of the Republic of Bulgaria in the field of scientific and technical cooperation, dated 1998, March 03]. Verkhovna Rada Ukrainy [Verkhovna Rada of Ukraine], [online]. Available at: http://zakon2.rada.gov.ua/laws/show/ru/100_097 [Accessed 02 March 2019].

15. Uhoda mizh Uriadom Ukrainy ta Uriadom Respubliky Bolhariia pro spivrobitnytstvo $\mathrm{v}$ haluziakh osvity, nauky i kultury vid 5.10.1992 r. [Agreement between the Government of Ukraine and the Government of the Republic of Bulgaria on cooperation in the spheres of education, science and culture, dated 1992, October 5]. Verkhovna Rada Ukrainy [Verkhovna Rada of Ukraine], [online]. Available at:https://zakon.rada.gov.ua/laws/show/ru/100_001 [Accessed 02 March 2019].

16. Uhoda pro asotsiatsiiu mizh Ukrainoiu, z odniiei storony, ta Yevropeiskym Soiuzom, Yevropeiskym spivtovarystvom z atomnoi enerhii i yikhnimy derzhavamychlenamy, $\mathrm{z}$ inshoi storonny vid 27.06 .2014 r. $\mathrm{v}$ redaktsii vid $30.11 .2015 \mathrm{r}$ [Association Agreement between Ukraine, on the one hand, and the European Union, the European Atomic Energy Community and their Member States, on the other hand, from 2014, June 27, revision 2015, November 30]. [Online]. Verkhovna Rada Ukrainy [Verkhovna Rada of Ukraine], [online]. Available at : http://zakon3.rada.gov.ua/laws/show/984_011 [Accessed 04 March 2019].

17. Ukraina rozghliadaie Bolhariiu yak druzhniu krainu i nadiinoho partnera zustrich Hlav Uriadiv [Ukraine considers Bulgaria as a friendly country and a reliable partner - a meeting of the Heads of Government]. (2019). Uriadovyi portal [Government portal], [online]. Available at: https://www.kmu.gov.ua/ua/news/ukrayina-rozglyadaye-bolgariyu-yak-druzhnyukrayinu-i-nadijnogo-partnera-zustrich-glav-uryadiv [Accessed 04 March 2019]. 
Міжнародні відносини: теоретико-практичні аспекти

Випуск 4 (2019)

ISSN (print) 2616-745X; ISSN (online) 2616-7794

18. Ukraina ta Bolhariia spivpratsiuvatymut u kosmichnomu eksperymenti "Ionosat-Mikro"' [Ukraine and Bulgaria will cooperate in the space experiment "Ionosat-Micro"]. TSN, [online]. Available at: https://tsn.ua/ukrayina/ukrayina-tabolgariya-spivpracyuvatimut-u-kosmichnomu-eksperimenti-ionosat-mikro683340.html [Accessed 02 March 2019].

(СБратко I. B., 2019 